\title{
Pola Kerja Work From Home dalam Industri Pendidikan Musik
}

\author{
Mohammad Insan Bagus Laksono \\ Universitas Paramadina, sonilaksono10@gmail.com
}

\begin{abstract}
ABSTRAK
Pandemi Covid-19 berhasil menghantam seluruh sektor dalam sisi kehidupan. Di aktivitas sehari-hari, penggunaan teknologi kian masif dilakukan di tengah wabah pandem. Hal itu adalah akibat dari adanya himbauan untuk tidak berkerumun ataupun sekedar bertatap muka secara fisik. Kondisi seperti inilah yang mencetuskan pola baru dalam bekerja, yakni work from home, yang mana menuntut pemaksimalan penggunaan teknologi.. Pun begitu dalam industri Pendidikan musik. Sekolah Musik Rumah Piano yang terletak di Kawasan Depok, Jawa Barat, sudah menerapkan kegiatan belajar mengajar dari rumah. Tenaga pengajar kini bekerja dengan sistem work from home. Hasil penelitian ini mendapatkan fakta bahwa di awal penerapan sistem work from home, ada beberapa kesulitan dalam proses adaptasi ketika mengajar. Hal itu karena belajar bermusik tidak mudah bila dilakukan secara daring. Namun, hasil wawancara menunjukkan bahwa pola kerja work from home memiliki prospek yang baik ke depannya. Sebab bisa menjadi win-win-solution bagi masing-masing pihak yakni dari segi perusahaan dapat menekan biaya, dari sisi pengajar bisa lebih efisien waktu, juga dari peserta didik yang tidak harus menempuh perjalanan menuju sekolah musik.Ke depannya pola belajar musik dengan daring akan dikombinasikan dengan sistem lama yakni offline untuk menjaga kualitas materi yang tersampaikan, meski diyakini tidak akan meninggalkan pola yang sekarang yakni online.
\end{abstract}

Kata Kunci : Covid-19, Pandemi, Work From Home, Sekolah Musik

\section{ABSTRACT}

The Covid-19 pandemic has successfully hit all sectors of life. In the implication of daily activities, the use of technology is increasingly being carried out in the midst of the corona pandemic outbreak. This is because of the appeal not to crowd or just meet face to face. Conditions like this have triggered a new pattern of work, namely working from home, which demands maximizing the use of technology in its continuity. Even so in the music education industry. The Piano House Music School, located in Depok, West Java, has implemented teaching and learning activities from home. This means that the teaching staff are now working from a home system. The results of this study were initially there were some difficulties in the adaptation process when teaching. That is while learning music is not easy if it is done boldly. However, the results of the interviews show that the work from home pattern has good prospects. Because it is a win-win-solution for each party, namely in terms of those who can bear the monthly fees, from the teaching side, they find time, so for students who do not have to travel to music school. However, learning music patterns will boldly cooperate with the old system, namely offline to maintain the quality of the material conveyed, will not leave the current pattern, namely online.

Keywords: Covid-19, Pandemic, Work From Home, Musik School 


\section{PENDAHULUAN}

Di era teknologi seperti saat ini, segala aktivitas komunikasi dituntut untuk bergerak dengan cepat. Tak bisa dipungkiri bahwa di zaman yang serba modern, segala bentuk komunikasi akan terafiliasi dengan penggunaan teknologi. Manusia, sebagai makluk sosial tentu melakukan segala aktivitas komunikasi setiap harinya. Hal ini senada dengan Dhita (2016), yang beranggapan bahwa di era modern seperti saat ini banyak perubahan dalam kehidupan yang terkait dengan teknologi informasi. Kenyataan yang terjadi saat ini adalah setiap individu tidak perlu bertatap langsung dengan lawan komunikasinya untuk melakukan aktivitas komunikasi. Pasalnya, segala jenis kegiatan komunikasi saat ini sudah dilakukan dengan hadirnya teknologi sebagai wadah atau media perantara antar individu atau kelompok dalam memenuhi kebutuhan komunikasinya dalam kehidupannya. Penggunaan teknologi dalam kegiatan berkomunikasi secara garis besar sudah mengalami perkembangan pesat dalam satu dekade ke belakang.

Terlebih, hadirnya sosial media juga semakin mempercepat -bahkan menjadi faktor utama-proses komunikasi dengan teknologi antar individu atau kelompok. Kita tentu ingat di sekitar sepuluh tahun lalu ketika banyak dari rekan-rekan jauh, yang sudah tidak menjadi bagian dalam hidup kita, tiba-tiba menjadi pribadi yang kembali dekat dengan hadirnya media sosial facebook -yang kala itu booming di Indonesia sekitar tahun 2009/10-an. Pun begitu dengan sosok individu yang sebelumnya bahkan tidak kita kenali, dengan hadirnya facebook di kala itu hingga saat ini-semakin mempermudah kita untuk melakukan kegiatan komunikasi secara intens yang tak jarang membuat hubungan tersebut kian erat.

Jika berbicara tentang komunikasi antar individu, Teori Penetrasi Sosial yang dipopulerkan oleh Irwin Altman \& Dalmas Taylor di tahun 1973, memiliki pembahasan menyoal kualitas dari proses komunikasi itu sendiri. Menurutnya, penetrasi sosial dalam kegiatan berkomunikasi merupakan proses bergeraknya suatu hubungan dalam berkomunikasi, bisa menjadi lebih dekat atau bahkan menjauh. teori ini dibagi menjadi tiga tingkatan, yakni; artificial level atau awal dalam sebuah hubungan, intimate level yaitu hubungan memasuki fase berproses, dan very intimate level atau hubungan yang intim. Ini artinya, teori penetrasi sosial berjalan secara bertahap. Mulai dari fase perkenalan, hingga tingkat mengenal secara personal (intim).

Hal ini jelas merupakan implikasi nyata dalam kehidupan bersosialiasi setiap orang. Di mana dalam sebuah perkenalan, tingkat keintiman komunikasi secara individu berkembang perlahan dari fase perkenalan. Yang unik adalah, Altman dan Taylor mengibaratkan manusia bagaikan sebuah bawang. Ya, mereka berpendapat bahwa terdapat lapisan-lapisan atau layer dalam tingkatan sebuah komunikasi. Dimulai dari lapisan terluar, hingga perlahan memasuki lapisan terdalam yang menyentuh bagian intim bawang, dalam hal ini adalah keintiman suatu hubungan yang dikupas satu persatu (step by step) lewat interaksiinteraksi tersebut. Menyoal teknologi dalam kualitas berkomunikasi, penulis meyakini bahwa kehadiran teknologi dalam proses berkomunikasi bak pisau bermata dua. Artinya, penggunaan teknologi dalam komunikasi bisa membuat suatu hubungan kian erat, dan dalam waktu yang bersamaan bisa juga membuat hubungan yang sebelumnya erat justru menjadi renggang.

Menurut Dede (2020), situasi pandemi corona membuat hampir seluruh sektor dalam lini kehidupan ikut terpukul. Termasuk industri media, bahkan pariwisata dan bisnis transportasi seperti pesawat.

Merujuk pada fenomena yang terjadi saat ini, tahun 2020 boleh jadi merupakan salah satu masa di mana peran teknologi dalam proses komunikasi meningkat pesat. Sebagaimana diketahui, hampir sepanjang tahun ini dunia dilanda wabah krisis kesehatan yakni wabah virus corona. Badan Kesehatan Dunia (WHO) sendiri sudah memberi klasifikasi virus tersebut menjadi sebuah pandemic - pandemi dalam Bahasa Indonesia. Ini, artinya, seluruh dunia kini dilanda penyakit yang sama dan menyebar luas dari sudut pandang geografis. 
Menyebarluasnya wabah virus corona membuat seluruh kegiatan dilakukan dari rumah untuk mengurangi mobiliasasi manusia dan membantu menghentikan penyebaran virus ini. Saat ini, di Indonesia dan seluruh negara lainnya, setidaknya sudah menggaungkan kegiatan bekerja di rumah atau dikenal dengan istilah work from home. Situasi seperti ini yang kemudian menuntut perusahan dari berbagai industri untuk mampu beradaptasi dengan pola bekerja work from home. Tentunya, untuk merealisasikan hal ini penggunaan teknologi saat ini harus mampu dimanfaatkan sepenuhnya.

Tak terkecuali industri pendidikan musik, yang mana sebelum datang wabah pandemi ini, sekolah-sekolah musik di Indonesia menjalankan aktivitas belajar mengajarnya dengan bertatap muka yang mana sekolah musik tersebut akan menjadi tempat pertemuan berbagai siswa dan guru musik secara fisik.

Hal, ini tentunya yang tidak bisa dipertahankan di masa wabah pendemi corona seperti saat ini. Alhasil, beberapa sekolah musik di Tanah Air kini menerapkan kebijakan work from home kepada para pekerjanya untuk melakukan kegiatan belajar mengajar terhadap anak didik mereka.

Salah satu sekolah musik yang menerapkan kebijakan ini adalah Sekolah Musik Rumah Piano. Sebuah sekolah musik yang berada di bilangan Depok, Jawa Barat, yang memaksimalkan teknologi dalam aktivitas belajar mengajarnya.

\section{KAJIAN LITERATUR}

\section{Komunikasi Massa}

Adapun kajian literatur pada penelitian ini yang pertama meliputi komunikasi massa. Yang mana, dalam kenyataannya, komunikasi massa berkaitan dengan khalayak ramai yang menggunakan saluransaluran tertentu dalam proses komunikasinya atau mengirim pesan. Hal itu meliputi media elektronik, cetak, maupun digital.

George Gerbner, penemu teori kultivas, menuturkan bahwa komunikasi massa sebagai proses distribusi dan produksi yang didasari oleh teknologi dan sebuah
Lembaga. Dalam hal ini, penyebaran informasi bisa dengan mudah dilakukan kepada khalayak ramai.

Selain itu, menurut Abdul (2013) komunikasi massa juga bisa lihat dalam dua sudut pandang. Yaitu adalah bagaimana seseorang membuat pesan dan mendistribusikannya melalui wadah media. Dan, juga bagaimana orang tersebut berupaya mencari dan menggunakan pesan tersebut pada pihak lainnya. Penggunaan komunikasi masa juga kerap dipengaruhi dinamika media massa dan penggunaannya olah banyak pihak. Dalam memahami pesan yang disampaikan dalam komunikasi massa, jelas diperlukan keahlian tersendiri. Contohnya seperti kemampuan menggunakan teknologi, melek huruf, dan paham konteksnya secara menyeluruh.

\section{New Media}

Selanjutnya adalah new media, atau media baru. Ini berkaitan dengan peran media di tengah kemajuan teknologi yang pesat sepert saat ini. Sebab, teknologi sudah menjadi bagian dalam kehidupan komunikasi orang banyak di saat ini. Kehadiran media baru juga membuat arus informasi kian tak terbatas hingga membus batasan-batasan ruang dan waktu.

Adapun karakteristik new media atau media baru di antaranya adalah; Digital, Interaktivitas, Jaringan (Network), Hipertekstual, Virtual, dan Simulasi.

Menurut Sri (2016), di era globalisasi seperti ini penggunaan media digital, online dalam sosial media berkembang dengan sangat pesat, sehingga sudah menjadi kebutuhan sehari-hari.

\section{Kovergensi Media}

Kajian literatur selanjutnya adalah konvergensi media. Yang mana meyakini bahwa hadirnya teknologi benar-benar membuat arus pertukaran informasi dan komunikasi antar pihak baik itu individu maupun kelompok menjadi benar-benar cepat menembus batas ruang waktu. Hal ini tentu berdampak pada kehidupan bermasyarakat sehari-hari, yang mana kehadiran teknologi internet dapat membentuk struktur tatanan dan identitas sosial di masyarakat luas.

Konvergensi media menitik beratkan pada pemaksimalan penggunaan teknologi. 
Dalam lingkup ekonomi media, teknologi selalu memiliki peran krusial di dalam industri media. Itulah mengapa infustri media massa harus terus berjalan seirama mengikuti perkembangan teknologi (Usman dalam Resmadi, 2014). Dengan begitu penggunaan teknologi akan memperluas cakupan penetrasi yang bisa dibuat oleh media. Tujuannya, konten yang dibuat dapat menyebar dalam lingkup yang lebih besar dan diterima khalayak ramai.

\section{METODE PENELITIAN}

Metode dalam penelitian ini adalah pendekatan kualitatif, yang mana memahami maksud dari paparan individu atau kelompok yang bersumber dari persoalan sosial atau pun kemanusiaan. Metode kualitatif ini juga berkaitan dengan pengajuan beberapa pertanyaan atau prosedur, mengumpulkan data secara jelas dari para sumber, dan menganalisa secara induktif yang dimulai dari tema khusus hingga tema umum dan penafsiran sebuah makna dalam data (Creswell, 2010). Sebuah penelitian kualitiatif juga berlandaskan pada konteks lokal di mana fenomena itu terjadi, generalisasi dari hasil penelitian terhadap populasi yang lebih luas dalam sebuah masalah (Lee dalam Mulyana, 2013).

Adapun penelitian ini memiliki jenis yakni deskriptif. Yang mana bertujuan untuk mendeskripsikan lewat cara sistemnatif, factual, dan akurat terkait fakta dan sifat objek atau populasi tertentu (Kriyantono, 2014). Penelitian deskriptif sendiri bertujuan untuk mengembangkan konsep, mengumpulkan fakta, dan bukan menguji sebuah hipotesis. Yang mana, berusaha mencari sebuah pola yang sederhana yang berlandaskan pada sebuah konsep (Bajari, 2015).

Penelitian ini sendiri memiliki metode studi kasus. Hal itu mengharuskan peneliti untuk bersifat kritis dalam memecah suatu masalah, peristiwa, dan aktivitas dari sumber. Kasus dalam penelitian ini juga dipbatasi waktu dan aktivitas. Dan, peneliti menghimpun informasi yang lengkap lewat bermacam prosedur pengumpulan data sesuai waktu yang telah ditentukan sebelumnya. Metode ini -studi kasusberpusat secara intensif kepada objek tertentu dengan cara mendalami kasus tersebut.

\section{TEKNIK PENGUMPULAN DATA}

Penulis mengumpulkan, menghimpun dan menganalisis data berupa fakta-fakta yang terjadi di lapangan untuk penelitian ini. Di antaranya dengan turut terlibat mengamati langsung dalam pola kerja work from home para guru di Sekolah Musik Rumah Piano selama masa pandemi corona. Guna mendapatkan data tersebut, penulis melontarkan pertanyaan dalam wawancara serta studi pustaka.

Adapun sumber berjenis primer dalam penelitian ini adalah hasil wawancara dengan pemilik Sekolah Musik Rumah Piano yang bernama Ibu Arini, serta guru gitar senior yang bernama Edwin Kharisman.

Penulis juga melakukan wawancara lain dengan staf admin Sekolah Musik Rumah Piano yang bernama Ibu Ina, yang dilakukan di kantor Sekolah Musik Rumah Piano di Jalan Cinere Raya Ruko no. 10A, Depok, Jawa Barat. Selain itu, sumber bersifat sekunder di penelitian ini tak lain adalah jurnal, buku, website terkait isu-isu terkini pola kerja work from home.

Adapun narasumber dala penelitian ini dipilih menggunakan prosedur purposif, yang mana dengan memilih kelompok yang menjadi sumber atau informan berdasarkan dengan kriteria terpilih yang relevan dengan kasus atau masalah dalam penelitian (Bungin, 2011).

Adapun pertimbangan memilih 3 nama di atas adalah karena; pertama, Ibu Arini sebagai pemilik sekolah musik yang menentukan arah dan kinerja sekolah musik semasa wabah virus corona. Kedua, bapak Edwin Kharisman ditunjuk lantaran sebagai guru paling senior yang menjadi rekan diskusi ibu Arini dalam mencari jalan ke luar di tengah wabah virus corona. Ia juga memantau kinerja beberapa guru lainnya, dan ikut mencetuskan pola belajar musik secara online. Dan, yang terakhir ibu Ina dipilih karena merupakan staff admin yang mana memiliki tugas akan kontrol terhadap seluruh kegiatan belajar mengajar musik. 


\section{PEMBAHASAN}

Sekolah Musik Rumah Piano sudah berdiri sejak tahun 2007, yang mana didirikan oleh pemiliknya saat ini yang juga merupakan narasumber, yakni Ibu Arini. Sekolah musik ini awalnya hanya wadah bagi murid-murid piano private Ibu Arini, yang kemudian berkembang merambah ke pengajaran alat musik lainnya sehingga menjadi sebuah sekolah musik.

Pengajaran alat musik gitar termasuk yang pertama dihadirkan di sekolah musik ini, yang mana narasumber kedua yakni Edwin Kharisman turut menjadi pencetus bidang tersebut di tahun 2009. Kini, sudah menjabat sebagai guru senior di Sekolah Musik tersebut.

Adapun Ibu Arini menuturkan bahwa ia sempat kehilangan murid-muridnya di awal wabah virus corona yakni sekitar di bulan Maret 2020. Lalu, ia mencetuskan pola belajar secara online dan menerapkan pola kerja work from home pada para tenaga pengajar. Rangkaian teknis work from home juga dirumuskan bersama Edwin Kharisman, sehingga perlahan jumlah murid kembali meningkat berkat pembukaan kelas secara online.

\section{Perubahan Pola Kerja}

Pola kerja secara work from home jelas membawa dampak berbeda dari biasanya. Terlebih, aktivitas belajar mengajar musik sebelumnya tak ladzim apa bila dilakukan secara daring.

Menurut ibu Arini, yang juga aktif sebagai guru piano, mengaku pola kerja work from home dengan mengajar piano secara daring membuat proses komunikasi terjadi salah paham. Hal itu juga membuat adanya perubahan dalam pola kerja.

'Ya, terkadang karena dia sedang bermain piano, dan saya memantaunya menggunakan handphone, jadi ketika bermain saya tidak bisa berkomunikasi, karena dia tidak dengar. Saya baru bisa mengoreksi setelah ia selesai bermain," kata ibu Arini.

'Namun, pola kerja kami jadi berubah karena harus menyiapkan materi video untuk dikirim dan bisa ia saksikan untuk dipelajari di luar jam les musik," tambahnya.
Senada dengan ibu Arini, Edwin Kharisman juga mengaku sempat kesulitan mengajar gitar kepada peserta didiknya. Adapun ia juga kini memiliki pola kerja baru yakni memantau guru-guru lainnya setiap hari via online.

'Saya sempat kesulitan awalnya untuk mengajar gitar secara online. Itu karena belum memiliki peralatan yang memadai. Kini, saya juga punya tugas lain untuk terus instens memantau kinerja guru-guru lainnya setiap hari via rapat zoom atau google meet," kata Edwin.

Adapun menurut Ibu Ina, di bagian staff admin tidak memiliki perubahan signifikan dalam pola kerja.

'Kalau kami (tim admin), tidak ada perubahan besar, yah. Hanya bekerja dari rumah saja. Mungkin yang berbeda kini kami harus terus saling mengabarkan progress kinerja sehari 2 kali di siang dan sore hari, lewat rapat online, sehingga produktivitas kami terjaga," kata Ibu Ina.

\section{Lebih Mudah Karena Teknologi}

Kendati sempat kesulitan beradaptasi dengan pola kerja baru, ketiganya sepakat kalau pola kerja work from home dengan memaksimalkan penggunaan teknologi, pekerjaan menjadi lebih mudah dan efisien terhadap waktu.

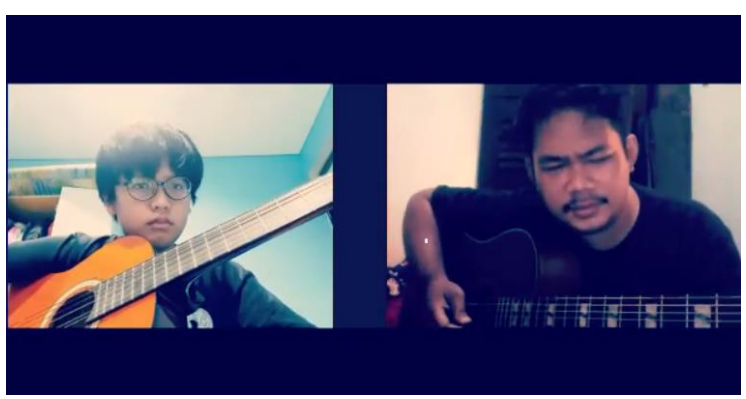

Bapak Edwin (kanan) mengajar peserta didik (kiri) menggunakan media video call. Foto: dok. pribadi

\footnotetext{
'Keuntungannya,, pekerjaan dilakukan dengan sangat mudah, dari rumah masingmasing. Itu jelas punya pengaruh besar karena sebagai ibu rumah tangga juga punya kewajiban lain di rumah," kata Ibu Arini.

'Ya, jelas. Karena semua berjalan secara online, saya juga bisa melakukan hal-hal lain tanpa harus berpindah-pindah lokasi yang jauh, '” tutur Edwin.
} 
'Untuk kami yang full bekerja di rumah, hal itu sangat menguntungkan karena bisa menghemat cost untuk ongkos sehari-hari sehingga bisa dialokasikan ke hal lain," jelas Ina.

\section{Prospek Work From Home}

Adapun perihal prospek pola kerja work from home ke depannya, Ibu Arini beranggapan bahwa pola kerja ini bisa diberlakukan dalam jangka panjang. Pasalnya, selain lebih efisien secara waktu, pola kerja work from home juga ikut menekan fixed cost maupun variable cost perusahaan.

Kendati begitu, untuk menjaga kualitas, ke depannya ibu arini akan mengkaji proporsi pembelajaran online dan offline. Sehingga, pola belajar mengajar musik akan kembali dilakukan secara tatap muka dalam jumlah pertemuan tertentu, yang bersifat sebagai kontrol langsung terhadap perkembangan anak didiknya.

'Ke depannya mungkin sistem kerja seperti ini akan kami pertahankan. Namun, kami terus mengevaluasi perihal proporsi belajar online dan offline. Saat ini, kami melakukan tatap muka atau offline hanya 2 kali dalam durasi 3 bulan. Hal itu mungkin akan bertambah menyesuaikan dengan kondisi ke depannya nanti. Yang jelas, itu (work from home) akan tetap dipertahankan karena mambawa banyak dampak positif," terang Ibu Arini.

Adapun wawancara terkait prospek pola kerja work from home ke depannya bersama Edwin adalah sebagai berikut;

"Soal itu, kembali lagi keputusan ada di atasan. Saya hanya membantu untk mengavaluasi setiap waktunya, mungkin porsi offline akan ditambah tanpa menghilangkan yang online," katanya.

\section{PENUTUP}

Wabah virus corona memang sudah membawa dampak besar bagi banyak sektor kehidupan. Salah satunya, yang relevan dalam penelitian ini adalah kegiatan belajar mengajar secara online dalam industry musik.

Banyak yang beranggapan bahwa kehidupan tidak akan kembali secara sedia kala, melainkan akan diganti dengan era new normal. Di era itu orang-orang dituntut untuk senantiasa selalu hidup bersih dan menjaga jarak dengan orang lain. Hal ini yang dinilai memang cukup membawa dampak baik secara kesehatan di samping adanya wabah virus corona.

Kesimpulan dalam penelitian ini adalah bahwa di awal wabah virus corona hadir di Indonesia, sekitar bulan Maret 2020, banyak orang yang tampak tak siap dengan hal itu, termasuk industri sekolah musik.

Pun begitu dengan Sekolah Musik Rumah Piano yang awalnya harus kehilangan banyak murid karena wabah virus corona. Mereka kemudian perlahan bangkit setelah menetapkan kebijakan work from home. Hal itu ternyata tidak berjalan mulus. Nyatanya, di awal penerapan kebijakan ini guru-guru kerap kesulitan menyampaikan materi kepada peserta didiknya.

Kendati begitu, banyak hal positif yang bisa diambil dari adanya wabah ini. Yang utama adalah memaksimalkan penggunaan teknologi. Sekolah Musik Rumah Piano memahami betul kini mereka dipaksa untuk memaksimalkan keberadaan teknologi. Dan, benar saja, pekerjaan justru lebih mudah jika individu berupaya untuk bersahabat dengan adanyanya teknologi. Sehingga, pola kerja yang berubah tersebut bisa diadaptasi dengan baik.

Kemudian, Sekolah Musik Rumah Piano menyadari bahwa kehidupan hanya akan masuk di era new normal, yang mana tak akan kembali lagi. Ini artinya, pola kerja work from home memiliki prospek untuk terus dipertahankan ke depannya, karena memiliki banyak dampak positif seperti efisiensi waktu hingga penghematan cost perusahaan.

Namun, guna menjaga kualitas peserta didik, Sekolah Musik Rumah Piano akan mengkaji kebijakan sistem kerjanya berdasarkan kondisi di masa depan.

Besar kemungkinan, mereka akan menambah porsi belajar musik secara offline tanpa meninggalkan pola kerja work from home yang dilakukan secara online.

\section{REFERENSI}

Bajari, Atwar. (2015). Metode Penelitian Komunikasi Prosedur, Tren, dan Etika. Bandung: Simbiosa Rekatama Media 
Bungin, Burhan. 2011. Penelitian Kualitatif. Jakarta: Kencana Predana Media Group

Creswell, John W. (2010). Research Design, Pendekatan Kualitatif, Kuantitatif, dan Mixed. Yogyakarta: Pustaka Pelajar.

Kriyantono, Rachmat. 2014. Teori Public Relations Perspektif Barat Dan Lokal: Aplikasi Penelitiandan Praktik. Jakarta: Kencana.

Mulyana, Deddy dan Solatun. (2013). Metode Penelitian Komunikasi: Contoh Penelitian Kualitatif Dengan Pendekatan Praktis. Bandung: Remaja Rosdakarya Resmadi, Idhar dan Sonny Yuliar. (2014).

Kajian Difusi Inovasi Konvergensi Media di Harian Pikiran Rakyat. Jurnal Sosioteknologi, Vol. 13, No 2, Hal 110118

Halik, Abdul. (2013). Komunikasi Massa. Makassar: Alauddin University Press.

Prasanti, Ditha (2016) Perubahan Media Komunikasi dalam Pola Komunikasi Keluarga di Era Digital, Jurnal ISSN.

Suprayitno, Dede (2020). Perubahan Pola Liputan Reporter TV Selama Pandemi COVID-19: (Jurnal Ilmu Komunikasi JIKA)

Yulianti, Sri (2016). Hubungan Daya Tarik Aplikasi Whatsapp dan Line dengan Keputusan Memilih Media Komunikasi untuk Pertemanan, Universitas Paramadina.

CNN Indonesia (2020), Mengenal Full Remote Work dan Bedanya dengan Work from home, artikel CNN Indonesia (https://www.cnnindonesia.com/gayahidup/20200615152206-284-

513484/mengenal-full-remote-work-danbedanya-dengan-work-from-home) diakses pada 20 November 2020

Kementrian Keuangan (2020), Work From Home Sebuah Paradigma Baru Budaya Kerja, Artikel DJKN, diakses pada 20 November 2020.
Puspita Ratna (2020), Dampak Covid-19, Pola Kerja dari Rumah Bakal Lebih Lumrah

(https://republika.co.id/berita/q8h10j428/d ampak-covid19-pola-kerja-dari-rumahbakal-lebih-lumrah) diakses pada 5 November 2020.

Samudra Adrian (2020) Ketahui Perbedaan Full Remote Work dan Work From Home (https://tirto.id/ketahui-perbedaan-fullremote-work-dan-work-from-home-fKjQ). Diakses pada 12 November 2020.

\section{BIODATA PENULIS}

Lahir di Jakarta, 10 Juni 1997, penulis merupakan pribadi yang cukup dekat dengan dunia musik.

Yang mana sedari kecil penulis sudah gemar mendengarkan dan memainkan alatalat musik. Hal inilah yang menjadi latar belakang penulis memilih tema yang berkaitan dengan musik dan dihubungkan dengan situasi masa kini, yang mana dunia sedang dilanda wabah virus corona yang membuat pekerjaan dituntut untuk bisa dilakukan di rumah.

Penulis saat ini merupakan mahasiswa aktif Universitas Paramadina jurusan Komunikasi Korporat 